\title{
Big Data and Smart Grid
}

\author{
Max v. Schönfeld and Nils Wehkamp
}

\begin{abstract}
Energy transformation is becoming digital: For several years now the EU has been pursuing the implementation of regulations for the digitalization of the energy networks. Electricity grids became more complex due to the focus on renewable energies; more efficient ways of energy management will be required: Smart Grid. The network load will be enhanced through gathering information regarding power consumption and production, as well as through automated decisions in the Smart Grid. Furthermore, the Smart Grid makes it possible to offer variable electricity rates; whereby, the price for the customer depends on the date of consumption. Legally, aspects of data protection and energy industry law play a major role. The rollout of smart meters in private households contains a substantial saving and optimization potential, and also enables the day-to-day lifecycles of households to be recorded in detail.
\end{abstract}

\section{The Energy Grid of the Future}

Smart Grid, Smart Metering, intelligent electricity grids-many expressions are used to describe the phenomena of the modern energy economy. The technological developments keep on drawing us closer to dystopian scenes out of fiction bookslike "1984" by George Orwell or "Blackout" by Marc Elsberg. ${ }^{1}$

We thank our colleague Tristan Radtke for his valuable comments.

${ }^{1}$ Cf. Pennell 2010, Smart Meter-Dann schalten Hacker die Lichter aus, Zeit Online, http://www. zeit.de/digital/internet/2010-04/smartgrid-strom-hacker.

M.v.Schönfeld $(\bowtie) \cdot N$. Wehkamp

Institute for Information, Telecommunication and Media Law (ITM), University of Münster,

Münster, Germany

e-mail: maxvonschoenfeld@uni-muenster.de

N. Wehkamp

e-mail: nils.wehkamp@uni-muenster.de

(C) The Author(s) 2018

T. Hoeren and B. Kolany-Raiser (eds.), Big Data in Context, SpringerBriefs in Law, https://doi.org/10.1007/978-3-319-62461-7_11 
The main objective of Smart Grids is to reduce the demand for electricity. ${ }^{2}$ Reductions have been made through integrating the so-called "Smart Meter", an intelligent electric meter, into German households. ${ }^{3}$ To date, the manually working Ferraris-meter has been the established standard, but now the modern Smart Meter will ensure a central and fully automatic recording of energy consumption in every household. Until 2020 - according to the plans of the EU-80\% of European households will be equipped with Smart Meters. ${ }^{4}$

Moreover, developments concerning E-Mobility ensure that, in addition to existing energy grids, further charging capacities will be made available and the overall demand for electricity will increase. ${ }^{5}$ The German energy transition will continue to be improved through intelligent energy networks and the developments regarding the coordination of the regulation of demand and supply in the Smart Grid. $^{6}$

Closely linked with the development of the electricity meters is the evolution of the interlaced field of home appliances. The keyword is "Smart Home". 7 However, due to the high investment costs, complete networking of all households is still a long way off. ${ }^{8}$

For quite some time now, politics and society have been confronted with the challenge to develop possible solutions to deal with big data in the energy sector. The basic legal framework regarding Smart Grids, and the technology behind it, will hereafter be illustrated.

\section{Smart Grid-The Basic Principles}

Prior to the energy revolution, the electricity grid had a comparatively simple structure. Households and factories were provided with energy by few big power plants. Fluctuations in energy demands, which would primarily be influenced by

\footnotetext{
${ }^{2}$ Schultz 2012, Smart Grid-Intelligente Netze können Strombedarf drastisch senken, Spiegel Online, http://www.spiegel.de/wirtschaft/unternehmen/smart-grid-kann-nachfrage-nach-stromenergie-drastisch-senken-a-837517.html.

${ }^{3}$ Resolution of the 80th Conference of data protection officers at November 3 and 4, 2010.

${ }^{4}$ See Annex I Nr. 2 of directive 2009/72/EG.

${ }^{5}$ Wiesemann, MMR 2011a, p 213 et seq.

${ }^{6} \mathrm{Cf}$. in regards to planning problems Schultz (2014), Energiewende-Dumm gelaufen mit den intelligenten Netzen, Spiegel Online, http://www.spiegel.de/wirtschaft/unternehmen/energie wende-intelligente-stromzaehler-kommen-zu-spaet-a-993021.html.

${ }^{7}$ Visser 2014, Hersteller setzen auf vernetzte Hausgeräte, Der Tagesspiegel, http://www.tagesspiegel. de/wirtschaft/neuheiten-auf-der-ifa-hersteller-setzen-auf-vernetzte-hausgeraete/10631904.html.

${ }^{8}$ Geiger 2011, Das Haus wird schlau, Süddeutsche Zeitung, http://www.sueddeutsche.de/digital/ cebit-vernetztes-wohnen-das-haus-wird-schlau-1.1065745.
} 
daily routines, could be balanced out by increasing or decreasing the power output. However, by focusing on renewable energies, the grid has become far more multilayered and will likely, in the future, become even more complex. ${ }^{9}$

An explanation being that the groups producing power have become more diverse. Besides traditional power plants, driven with fossil fuels, various wind and solar farms, as well as private households equipped with photovoltaic systems nowadays make up the grid. Additionally, improvements in storage technology offer reliable opportunities for households to save power on a smaller scale. ${ }^{10}$

However, renewable energies also have certain disadvantages. On one hand, they are not yet able to reliably and continuously produce energy with high efficiency ratings, since they are - after all — dependent on environmental and weather factors. Wind turbines are dependent on wind force and solar plants are only able to produce energy during the day. On the other hand, they feed the produced energy into the lower voltage level of the grid and can therefore only be used to a limited extent in rural areas. ${ }^{11}$ As a consequence, grids are becoming more regional as consumers and producers are, geographically, moving closer together. ${ }^{12}$

Smart Grid deals with this complexity by gathering detailed information from each user of the grid. This information serves as a basis to enable the interaction between the individual storage facilities, producers and consumers to be coordinated in the best possible way and to ensure a reliable power supply, even in regional grids. ${ }^{13}$ Thus, a Smart Grid is not only a means to optimize the supply of energy itself, but also provides the infrastructure, which is necessary for a successful energy revolution. Additionally, reduced power consumption leads to a reduction in $\mathrm{CO}_{2}$ emissions.

This also enables operators of the grid infrastructures to have new opportunities for economic savings. By better balancing power output and through additional storage possibilities, the grip operators' costs of infrastructure can be reduced. ${ }^{14}$

\footnotetext{
${ }^{9}$ Cf. German Federal Government, Energiewende-Maßnahmen im Überblick, https://www. bundesregierung.de/Content/DE/StatischeSeiten/Breg/Energiekonzept/0-Buehne/ma\%C3\%9Fnah men-im-ueberblick.html;jsessionid=C7CC13BD940CBF9899D49D6D95E1DC56.s4t2.

${ }^{10}$ Dötsch et al., Umwelt Wirtschafts Forum 2009, p 353.

${ }^{11}$ German Federal Office for Information Security (BSI), Smart Metering-Datenschutz und Datensicherheit auf höchstem Niveau, https://www.bmwi.de/Redaktion/DE/Downloads/S-T/ smart-metering.pdf?_blob=publicationFile $\& \mathrm{v}=3$. Classically, a power grid consists of four voltage levels (transmission grid, high voltage, medium voltage, low voltage). The higher the voltage level is, the better suited it is for the long distance energy transmission. The transport, as well as the transformation between the voltage levels, lead to energy losses and should therefore be minimized whenever possible, see Kamper, Dezentrales Lastmanagement zum Ausgleich kurzfristiger Abweichungen im Stromnetz, https://publikationen.bibliothek.kit.edu/1000019365, p 11.

${ }^{12}$ Cf. Ausfelder et al., Chemie Ingenieur Technik 2015 (87), p 20.

${ }^{13}$ Rehtanz, Spektrum der Informatik 2015 (38), p 19.

${ }^{14}$ Neumann, Zeitschrift für Energiewirtschaft 2010(34), p 279 et seqq.
} 


\subsection{Smart Grid-A Definition}

The term "Smart" has been turned into a buzzword in the context of big data topics. Roughly described, it is a technological approach through which the networking of users by gathering and analyzing as much data as possible should become more efficient and user-friendly. For the energy grid, this means collecting data from the power production, the consumption, and stored reserves. With the collected data, the consumption of every single user will be automatically harmonized. What finally makes an energy grid a "Smart Grid" is the collection of data and the use of automated decision-making processes. ${ }^{15}$ In practice, in the future, a house will be equipped with energy storage and solar cells. On the basis of the information about the network load, the own consumption, and the self-produced energy, the household can automatically decide whether it wishes to consume, save, or feed the local grid with the self-produced power.

In case of a high network load, the power will be saved or consumed automatically; however, in case of a low network load, the power will be fed into the grid and the own storage will-when required - even be discharged into the grid. When there is little sun - and, as a result, a lack of solar energy - the power will, in turn, be completely drawn from the grid. These decisions are complex, but are exercised automatically so that the consumer does not need to deal with them in everyday life.

The Smart Grid does not only offer decision-making support for the household, but also for the network management. Decisions about the charging or discharging of energy storages and the adaption of the power plant output on the basis of collected data are made here as well. For this purpose, all data on production and consumption, from the public power plants as well as from the households, will be gathered from the network operators.

\subsection{Which Data Are Required?}

Which data are precisely gathered and processed for the decision-making process? Besides the current data on production and consumption, meteorological data and forecasts, as well as, previous data consumption, will be recorded. Through this, combined data algorithms will be able to recognize patterns and connections. On this basis, it is possible to create forecasts regarding the network load. ${ }^{16}$ An example for such a data relationship is the one between outdoor temperatures and the power consumption of air conditioners. As soon as the outdoor temperatures

\footnotetext{
${ }^{15}$ Von Oheimb 2014, IT Security architecture approaches for Smart Metering and Smart Grid, http://david.von-oheimb.de/cs/papers/Smart_Grid-Security_Architecture.pdf, p 2.

${ }^{16}$ Potter et al. 2009, Building a Smarter Smart Grid through better renewable energy information, http://citeseerx.ist.psu.edu/viewdoc/download?doi=10.1.1.469.6941\&rep=rep1\&type=pdf, p 4 .
} 
rise, the power consumption will increase by a certain factor. By means of such connections and through the weather forecast, supply services will be able to predict fluctuations in power consumption and undertake appropriate measures to keep the network load stabilized.

\subsection{Smart Meter-The Electricity Meter with an Internet Connection}

The Smart Meter is part of the Smart Grid, which adds the consumer to the cycle. Thereby the modern technology allows it to not only record the annual consumption of each household, but to be able to record the consumption in minute intervals. ${ }^{17}$ This has some advantages for the consumer. For example, the consumer has the opportunity to control his/her consumption and this can result in potential saving opportunities.

The structure of a Smart Meter is different from state to state, because they need to adhere to country-specific regulations and laws. In Germany, the communication module - the Smart Meter Gateway_plays a particularly crucial role. The energy (or alternatively gas and water) consumption is still captured by individual meters. Yet, with Smart Metering, these operate electronically - in contrast to the remaining widespread mechanical Ferraris meters. The collected data can thereby be transmitted digitally. For this purpose, the meters are connected with the abovementioned communication module. Thus, forming the interface where the meter's data are bundled and eventually sent to the network operator. ${ }^{18}$ In Germany, the consumption fees should, in the future, be determined directly in the device itself, in order to reduce the amount of data sent to the supplier. The supplier then only receives information regarding the data of the amount of consumed power, instead of the consumption data and the exact time of the consumption.

Separating both the individual meter and the communication module has the advantage that the measuring intervals and communication with the network operator can be decoupled from one another. As a consequence, it is then possible to control on which frequency and how summarized, the consumption data is transmitted to the supplier, without having individuals waive the opportunity to observe their own live-consumption data. ${ }^{19}$ Moreover, several individual meters can be connected to one communication module, so that one module can be used by

\footnotetext{
${ }^{17}$ The exact frequency of data transmission is still controversial. Scientific publications name intervals between $2 \mathrm{~h}$ and $2 \mathrm{~min}$.

${ }^{18}$ German Federal Office for Information Security (BSI), Das Smart-Meter-Gateway Sicherheit für intelligente Netze, https://www.bsi.bund.de/SharedDocs/Downloads/DE/BSI/Publikationen/ Broschueren/Smart-Meter-Gateway.pdf?_blob=publicationFile, p 13 et seqq.

${ }^{19}$ Mrs. Voßhoff, the Federal Data Protection Commissioner, talks about a "successful Privacy by Design": http://www.golem.de/news/smart-meter-gateway-anhoerung-stromsparen-geht-auchanders-1604-120319.html.
} 
several households, for instance in an apartment building - thereby minimizing the costs of the new hardware for the consumers. ${ }^{20}$ Consequently, not only can the supplier request consumption data from the households, but the household can in reverse find out the current price for electricity. ${ }^{21}$ This is a basic requirement in order to be able to allow the consumer to play an active role in the electricity market.

The Smart Meter Gateway could also be used as a transformer station for a Smart Home network whereby further automation opportunities will be created. ${ }^{22}$

The possibility to transmit consumption data in minute intervals does not come without problems for the protection of privacy. Consumption data are ultimately influenced by various methods of behavior, because each electronic device has a certain consumption pattern. If consumption data of households are compared to the consumption data of devices, conclusions can be drawn regarding which devices were used at what time. Thus a behavioral profile can be created. ${ }^{23}$

\subsection{Impeding Ability to Draw Conclusions}

These prospects can be impeded by various factors. Firstly, the decoupling of meter and intervals of communication, as mentioned above, is expedient. A new trade-off must be made in regards to how strongly pooled the consumption data are transmitted to the supplier. Data which are bundled too strongly oppose the aim of a Smart Grid - due to the loss of abstraction —; whilst real time transmission of data constitutes a huge intervention into privacy.

Secondly, a further measure to face concerns regarding privacy is the collection of consumption data from various households to counteract detailed conclusions. This would not only protect the privacy but also improve the quality of consumption prognoses. After all, in the short term, forecasts regarding the behavior of household residents are often unreliable because these regularly deviate from average behavioral patterns. The collection of several households is, in fact, promising, as possible deviations would balance each other out and lead to an overall higher informative value of the forecasts. ${ }^{24}$ Consequently, it has to be considered which level of detail of the collected data has to be carried out - not only in the interest of privacy protection but also in the interest of network operators.

\footnotetext{
${ }^{20}$ However, this can lead to a conflict of interests between landlord and tenant: http://www.golem. de/news/zwangsbeglueckung-vernetzte-stromzaehler-koennten-verbraucher-noch-mehr-kosten1604-120166.html.

${ }^{21}$ Fox, DuD 2010, p 408.

${ }^{22}$ German Federal Office for Information Security (BSI), Das Smart-Meter-Gateway Sicherheit für intelligente Netze, https://www.bsi.bund.de/SharedDocs/Downloads/DE/BSI/Publikationen/Brosc hueren/Smart-Meter-Gateway.pdf?_blob=publicationFile, p 35 et seq.

${ }^{23}$ McKenna et al., Energy Policy 2012, p 807 et seqq.

${ }^{24}$ Da Silva et al., IEE Transactions on Smart Grid 2014 (5), p 402.
} 


\subsection{Smart Market}

The term Smart Market is thematically often used in connection with the term Smart Grid but is, strictly speaking, a new market model which can be achieved through a Smart Grid. Due to the fact that the electricity consumption can be captured in minute intervals, rather than annually, and due to the opportunities for communication between the supplier and the consumer, a liberalization of the price policy can be realized. At the annual reading, the customer, until now, paid the price for his consumption, which was previously agreed upon. However, the price is subject to major fluctuations and a result of supply and demand. ${ }^{25}$

\subsection{Variable Tariffs and Its Profiteers}

Variable tariffs, in the context of Smart Market, means that electricity costs may be varied at different times of the day and are dependent on the current network load. The optimization of the network load and the reduction of the electricity consumption are also pursued as aims. In a Smart Grid, this should be done by analyzing information and automated decisions, whereas in a Smart Market this should be achieved by optimizing the market behavior. ${ }^{26}$ At times of high electricity prices, it is assumed that the customer postpones energy-intensive and expensive activities until a time when the power is cheaper. Therefore, the electricity price reflects the situation of supply and demand in the grid. The customer reacts on the current situation of the market and, as a result, adapts his consumption. ${ }^{27}$

Whether the consumer benefits from such variable tariffs depends on his/her flexibility. If it is possible to postpone energy-intensive activities, such as doing the laundry, to a time when electricity is cheaper, electricity costs can thereby be reduced. However, disadvantages occur for consumers who are less flexible, for various reasons. For instance, people dependent on care who require assistance cannot do their laundry at any time of the day. Even unimpaired people cannot move certain activities to cheaper times of the day, for example, when a meal must be prepared.

In the medium-term, the costs of purchasing smart infrastructure will principally be decisive for whether the consumer has an economic advantage. ${ }^{28}$ According to a

\footnotetext{
${ }^{25}$ Liebe et al., Quantitative Auswirkungen variabler Stromtarife auf die Stromkosten von Haushalten 2015, p 11.

${ }^{26}$ Doleski/Aichele 2014, Idee des intelligenten Energiemarktkonzepts, in: Smart Market: Vom Smart Grid zum intelligenten Energiemarkt, p 18.

${ }^{27}$ Grösser/Schwenke, Kausales Smart Market Modell als Basis für Interventionen: Abschlussbericht 2015 der Arbeitsgruppe Smart Market des Vereins Smart Grid Schweiz, p 18 et seqq.

${ }^{28}$ Liebe et al. 2015, Quantitative Auswirkungen variabler Stromtarife auf die Stromkosten von Haushalten, p 9.
} 
Forsa survey, consumers are, in principle, interested in variable tariffs but they also fear a too intensive intervention into their personal daily life and due to the increased complexity doubt the practicability in everyday life. ${ }^{29}$

\section{Legal Framework}

Big data in the realm of Smart Grids comes with significant legal challenges. Thus, the legal framework for information technology in German law will be outlined and explained. Energy law, data protection law, and IT-security law can here be named as essential topics. Sources of law can be found in the Energiewirtschaftsgesetz (EnWG; German Energy Industry Act), in the Bundesdatenschutzgesetz (BDSG; Federal Data Protection Act) and the Gesetz zur Erhöhung der Sicherheit informationstechnischer Systeme (IT-Sicherheitsgesetz; IT-Security Act). Beforehand, basic regulatory approaches in the USA and the EU will briefly be compared. In 2018, the General Data Protection Regulation (GDPR) will be applicable regarding data protection law.

\subsection{Regulation in the USA and Europe-An Overview}

The development of Smart Grids in the USA and the EU is by all means quite comparable, however in the EU on a delayed basis. Early on, the USA focused on implementing regulations. A few years ago, Acts like the Energy Independence and Security Act of 2007 (EISA), the Federal Energy Regulatory Commission Smart Grid Policy, and the Recovery and Reinvestment Act of 2009 (ARRA), have already set standards for the Smart Meter and its corresponding interactions of the systems, regulated security issues and provided subsidies. ${ }^{30}$

On a European level, the EU Energy Efficiency Directive (2012/27/EU) contains arguably the most important specifications. In article 9 of the Directive 2012/27/EU the regulations regarding Smart Meters can be found. The member states have to ensure the provision of Smart Meters at competitive prices pursuant article 9 subs. 1 of Directive 2012/27/EU. According to article 9 subs. 2 of the provision, member states are furthermore, expected to ensure the data protection of Smart Meters and the consumers access to parts of the measured data. All in all, the EU's focus lies, until now, on the research and development of Smart Grid technologies. ${ }^{31}$ As an

\footnotetext{
${ }^{29}$ Verbraucherzentrale Bundesverband, Akzeptanz von variablen Stromtarifen, p 66.

${ }^{30}$ Zhang 2011, Public Utilities Fortnightly 2011, p 49.

${ }^{31}$ European Commission 2016, Smart Grids and Meters, https://ec.europa.eu/energy/en/topics/ markets-and-consumers/smart-grids-and-meters.
} 
example, the study on possible security systems around Smart Grid by ENISA (European Union Agency for Network and Information Security) can be named. ${ }^{32}$ Such specific legal acts for the regulation of Smart Grid and its components, like in the USA, have not yet been issued on a European level but are in the planning stage. $^{33}$

In Germany, the Energy Industry Act has, since 2010, provided new construction projects or substantial renovations and provided that new electricity meters replace the older ones. A draft by the Federal Government regarding the digitalization of the energy revolution is currently being discussed.

\subsection{Legal Implications and Concerned Areas of Law}

This topic entails various legal implications. Firstly, the question arises as to how the intelligent use of energy can be made available for individual households. Besides state subsidies, an obligation to use Smart Meters is also possible. ${ }^{34}$ Energy law is of particular importance. In the context of data protection law, for the functionality of the Smart Grid, it needs to be determined which data needs to be and which data can be transmitted to individual providers. In accordance with the requirements of the German Federal Network Agency, the legal implications of Smart Grids have to be clearly differentiated from those of the Smart Market, meaning measures have to be taken for a better integration of renewable energies into the grids, and innovative tariff system. ${ }^{35}$

\subsection{The Smart Meter in the German Household}

Energy law provides answers to the question whether the use of Smart Meters in the individual household can be and should be standardized. Within section 40 subs. 5 EnWG German law states, that the energy suppliers have to offer the consumers a tariff-provided that it is technical feasibility and economic reasonable-which incentives saving energy or controlling energy consumption. According to section 21 (c) subs. 1 (a) EnWG, meter operators are obliged to install Smart Metersif technically possible-, amongst others, in new buildings and major renovations as

\footnotetext{
${ }^{32}$ ENISA 2013, Proposal for a list of security measures for smart grids, https://ec.europa.eu/energy/ sites/ener/files/documents/20140409_enisa_0.pdf.

${ }^{33}$ In detail: Hoenkamp 2015, Safeguarding EU Policy Aims and Requirements in Smart Grid Standardization, $\mathrm{p} 77$ et seqq.

${ }^{34}$ Süddeutsche Zeitung.de, Intelligente Stromzähler Regierung dementiert Bericht zu Zwangs abgabe, http://www.sueddeutsche.de/geld/intelligente-stromzaehler-regierung-dementiert-berichtzu-Zwangsabgabe-1.1832298.

${ }^{35}$ Bundesnetzagentur, MMR-Aktuell 2012, 327271.
} 
outlined in sections 21 (d), 21 (e) EnWG. This is effective for consumers with an energy consumption of more than $6000 \mathrm{kWh}$ pursuant to section 21 (c) subs. 1 (b) EnWG, and likewise for other buildings pursuant to s. 21 (c) subs. 1 (d) EnWG. ${ }^{36}$

Therefore, Smart Meters are already installed in new buildings and modifications. New incentives are being set through obliging energy suppliers to provide appropriate tariffs. ${ }^{37}$

\subsection{Aspects of Data Protection}

The requirements of data protection law are an important legal issue for the use of Smart Grids. ${ }^{38}$ The focus here lies on data, which are collected and processed by Smart Meters. Area-specific data protection law is primarily applicable but the general principles of the BDSG apply as well.

Thus, the principle of data avoidance pursuant to section 3 (a) BDSG must also be observed when using Smart Meters. Depending on the technical configuration, this can be achieved, for example, by processing the majority of the data within the Smart Home. ${ }^{39}$ As of today, the collection, processing and usage of personal data are only permitted in the limits of section 21 (g) subs. 1 EnWG. Personal data areaccording to the legal definition in section 3 subs. 1 BDSG-details regarding personal or factual relations of an identified or an identifiable natural person.

The provision of section 21 (g) EnWG conclusively regulates which purposes are regarded as acceptable and is, therefore, a more specific provision than section 28 BDSG which only regulates on the data collection and storage for business purposes in general. Such data, which traditionally accrue from measuring the energy consumption, or from the supplying and feeding-in of energy, are to be named as relevant data. The opportunity to collect and process data, which are required for variable tariffs pursuant to section 40 subs. 5 EnWG, is attractive.

In the context of these variable tariffs it can be decidedly determined - due to the relevant data - when each appliance can be used most efficiently. Moreover, in section 21 (h) EnWG the extensive information options for the owners of a connection are listed. To what extent the General Data Protection Regulation, which becomes effective in 2018, will bring about changes, remains to be seen.

\footnotetext{
${ }^{36}$ Wiesemann, MMR 2011b, 355 (355 et seq.).

${ }^{37}$ Critical regarding costs and Kritisch zu den Kosten und der Effektivität Biermann, Stromkunden sollen sich überwachen lassen - und dafür zahlen, ZEIT Online, http://www.zeit.de/digital/ datenschutz/2013-11/smart-meter-teuer-daten-vermarkten.

${ }^{38}$ Entschließung der 80. Konferenz der Datenschutzbeauftragten des Bundes und der Länder vom 3./4. November 2010, http://www.bfdi.bund.de/SharedDocs/Publikationen/Entschliessungss ammlung/DSBundLaen-der/80DSK_DatenschutzBeiDerDigitalenMessung.pdf?_blob=publica tionFile \& $v=1$.

${ }^{39}$ Lüdemann et al., DuD 2015, 93 (97).
} 


\subsection{The Draft Law on the Digitalization of the Energy Revolution}

Currently, a draft digitalization of the energy revolution by the Federal Government is in the parliamentary legislative procedure. ${ }^{40}$ The aim of the draft is a reasonable distribution of costs between the consumers and the suppliers under the warranty of data protection and data safety in Smart Grid. For this, the developed standards for section 21 (e) EnWG are to be generalized.

The draft addresses the industry, the energy suppliers and, in the medium term, and also private households. It contains three central areas of regulation. Firstly, technical minimum requirements are to be applied to the use of intelligent measurement systems. This is especially achieved through the development of so-called protection profiles, which are developed in close corporation with the Bundesministerium für Wirtschaft und Forschung (Federal Ministry for Economic Affairs and Energy), the Bundesamt für Sicherheit in der Informationstechnik (Federal Office for Information Security), the Bundesbeauftragter für den Datenschutz (Federal Commissioner for Data Protection), the Bundesnetzagentur (Federal Network Agency) and the Physikalisch-Technische Bundesanstalt (National Metrology Institute of Germany). Secondly, the permissible data communication is to be regulated in due consideration of data protection and data security as benchmarks. Lastly, the regulation on the operation of metering points will be pursued to set the framework for a future cost-efficient and consumerfriendly metering point operation suited to the energy revolution.

Thus, the draft should be seen as a further development to the 2011 EnWG reforms. Private households, in which a Smart Meter will be installed, will have to carry costs of up to 100 euros, which, in turn, are supposed to be compensated by energy saving potentials. The draft's incentives seem to be useful and appropriate; the concrete effects, in case of an implementation, remain to be seen. ${ }^{41}$ It is certainly clear that Germany will start with the market launch of intelligent measurement technology. ${ }^{42}$

\subsection{General Questions Regarding the Legal Treatment of Data in the Big Data Era}

Fundamental legal questions are very important in the context of Smart Grid and Smart Meter, as it is the case in other big data application sectors. When dealing

\footnotetext{
${ }^{40}$ Draft can be found under BT-Drucks. 18/7555 (printed paper of the Parliament 18/7555), available at http://dipbt.bundestag.de/dip21/btd/18/075/1807555.pdf.

${ }^{41}$ Critically Welchering, Deutschlandfunk Online, http://www.deutschlandfunk.de/datenschutz-imsmart-home-ohne-abgesicherte-infrastruktur.684.de.html?dram:article_id=351502.

${ }^{42}$ Summarized by Wege/Wagner, Netzwirtschaften und Recht 2016, 2.
} 
with large datasets, the question arises as to how effective data will be protected from access by third parties. Through the IT Security Act (IT-Sicherheitsgesetz) critical infrastructure providers are, pursuant to s. 8 (a) subs. 1, sentence 1, para. 3 Act on the Federal Office for Information Security (Gesetz über das Bundesamt für Sicherheit in der Informationstechnik) legally obliged to provide technical protection and to prove this to the Federal Office for Information Security (Bundesamt für Sicherheit in der Informationstechnik) regularly. According to s. 2 subs. 10, critical infrastructures are, amongst others, institutions or facilities from the energy sector provided that supply shortfalls are likely to occur during times of a breakdown. Furthermore, superordinate questions arise regarding the requirement of legal ownership of data or the handling of data quality in light of liability issues. Protection opportunities under the intellectual property law exist, for instance pursuant section $87 \mathrm{a}$ et seq. UrhG (Copyright Act). These are entirely investment protections, which safeguard the methodically and systematically arranged collection of data.

\section{Summary and Outlook}

It is certain that Smart Grid and Smart Meter have the potential to substantially change the private household as an institution. In the future, intelligent measuring systems will not only be able to measure, to manage, and to transmit the power consumption, but may prospectively be able to manage and control the demand for gas, water, and thermal heat. The energy use in a person's own household enables detailed profiles about an inhabitant's daily routine and their usage habits. In the USA, the first legal acts, which regulated the Smart Grid, were already passed some years ago. In the EU, and in Germany in particular, special legal acts, which regulate central legal questions of data protection, data safety and the use of Smart Meters are still in progress.

It remains to be seen as to how long it will take until the majority of the German households will be equipped with Smart Meters. Moreover, it needs to be demonstrated whether the new regulations are in their practical application, in fact, able to sufficiently provide the necessary guarantees for data protection and data safety, contrary to the expectations of its critics. If this is the case, Smart Metering could be an important cornerstone for the path to the revolution of energy.

\section{References}

Aichele C, Doleski OD (2014) Smart Market: Vom Smart Grid zum intelligenten Energiemarkt. Springer, Berlin

Biermann K (2013) Stromkunden sollen sich überwachen lassen - und dafür zahlen, Zeit Online. http://www.zeit.de/digital/datenschutz/2013-11/smart-meter-teuer-daten-vermarkten. Accessed 4 Apr 2017 
Brunekreeft $\mathrm{G}$ et al. (eds) (2010) Regulatory pathways for smart grid development in China. Zeitung Energiewirtschaft 34:279-284

Bundesamt für Sicherheit in der Informationstechnik (2015) Das Smart-Meter-Gateway_Sicherheit für intelligente Netze. https://www.bsi.bund.de/SharedDocs/Downloads/DE/BSI/Publikatio nen/Broschueren/Smart-Meter-Gateway.pdf?_blob=publicationFile. Accessed 4 Apr 2017

Bundesamt für Sicherheit in der Informationstechnik (n.a.) Smart Metering-Datenschutz und Datensicherheit auf höchstem Niveau. http://www.bmwi.de/BMWi/Redaktion/PDF/S-T/smartmetering,property=pdf, bereich=bmwi,sprache=de,rwb=true.pdf. Accessed 4 Apr 2017

Bundesnetzagentur (2012) "Smart Grid" und "Smart Market". https://www.bundesnetzagentur. de/SharedDocs/Downloads/DE/Sachgebiete/Energie/Unternehmen_Institutionen/Netzzugang UndMesswesen/SmartGridEckpunktepapier/SmartGridPapierpdf.pdf?__blob=publicationFile . Accessed 4 Apr 2017

Bundesregierung (2016) Energiewende_Maßnahmen im Überblick. https://www.bundesregierung. de/Content/DE/StatischeSeiten/Breg/Energiekonzept/0-Buehne/ma\%C3\%9Fnahmen-im-ueber blick.html;jsessionid=C7CC13BD940CBF9899D49D6D95E1DC56.s4t2. Accessed 4 Apr 2017

Dötsch C, Kanngießer A, Wolf D (2009) Speicherung elektrischer Energie-Technologien zur Netzintegration erneuerbarer Energien

ENISA (2013) Proposal for a list of security measures for smart grids. https://ec.europa.eu/energy/ sites/ener/files/documents/20140409_enisa_0.pdf. Accessed 24 Aug 2016

European Commission (2016) Smart grids and meters. https://ec.europa.eu/energy/en/topics/ markets-and-consumers/smart-grids-and-meters. Accessed 4 Apr 2017

Forsa main Marktinformationssysteme GmbH (2015) Akzeptanz von variablen Stromtarifen. http://www.vzbv.de/sites/default/files/downloads/Akzeptanz-variable-Stromtarife_UmfrageForsa-vzbv-November-2015.pdf. Accessed 4 Apr 2017

Fox D (2010) Smart meter. DuD 34:408

Geiger M (2011) Das Haus wird schlau, Süddeutsche Zeitung. http://www.sueddeutsche.de/digital/ cebit-vernetztes-wohnen-das-haus-wird-schlau-1.1065745-2. Accessed 4 Apr 2017

Goncalves Da Silva P, Ilic D, Karnousko S (2014) The impact of smart grid prosumer grouping on forecasting accuracy and its benefits for local electricity market trading

Grösser S, Schwenke M (2015) Kausales SmartMarket Modell als Basis für Interventionen: Abschlussbericht 2014 der Arbeitsgruppe Smart Market des Vereins Smart Grid Schweiz

Hayes B, Gruber J, Prodanovic M (2015) Short-term load forecasting at the local level using smart meter data. http://smarthg.di.uniroma1.it/refbase/papers/hayes/2015/51_Hayes_etal2015.pdf. Accessed 4 Apr 2017

Hoenkamp R (2015) Safeguarding EU policy aims and requirements in smart grid standardization

Konferenz der Datenschutzbeauftragten des Bundes und Länder (2010) Entschließung der 80. Konferenz vom 3./4. November 2010

Liebe A, Schmitt S, Wissner M (2015) Quantitative Auswirkungen variabler Stromtarife auf die Stromkosten von Haushalten. http://www.wik.org/fileadmin/Studien/2015/Auswirkungenvariabler-Stromtarife-auf-Stromkosten-Haushalte-WIK-vzbv-November-2015.pdf. Accessed 4 Apr 2017

Lüdemann V, Scheerhorn A, Sengstacken C, Brettschneider D (2015) Systemdatenschutz im smart grid. DuD 39(2):93-97

McKenna E, Richardson I, Thomson M (2011) Smart meter data: balancing consumer privacy concerns with legitimate applications

Neumann N (2010) Intelligente Stromzähler und -netze: Versorger zögern mit neuen Angeboten. ZfE 34(4):279-284

Pennell J (2010) Smart Meter-Dann schalten Hacker die Lichter aus, Zeit Online. http://www. zeit.de/digital/internet/2010-04/smartgrid-strom-hacker. Accessed 4 Apr 2017

Potter C, Archambault A, Westrick K (2009) Building a smarter smart grid through better renewable energy information. In: Power systems conference and exposition, 2009. PSCE '09. IEEE/PES 
Rehtanz C (2015) Energie 4.0-Die Zukunft des elektrischen Energiesystems durch Digitalisierung. Informatik-Spektrum 38(1):16-21

Roy T (2015). Intelligente Energiesysteme der Zukunft: Die Entwicklung von Smart Metering und Smart Grid im Jahre 2025

Schultz S (2012) Smart Grid - Intelligente Netze können Strombedarf drastisch senken, Spiegel Online. http://www.spiegel.de/wirtschaft/unternehmen/smart-grid-kann-nachfrage-nach-stromenergie-drastisch-senken-a-837517.html. Accessed 4 Apr 2017

Schultz S (2014) Energiewende-Dumm gelaufen mit den intelligenten Netzen, Spiegel Online. http://www.spiegel.de/wirtschaft/unternehmen/energiewende-intelligente-stromzaehlerkommen-zu-spaet-a-993021.html. Accessed 4 Apr 2017

Süddeutsche Zeitung (2013) Intelligente Stromzähler: Regierung dementiert Bericht zu Zwangsab gabe. http://www.sueddeutsche.de/geld/intelligente-stromzaehler-regierung-dementiert-berichtzu-zwangsabgabe-1.1832298. Accessed 4 Apr 2017

Visser C (2014) Hersteller setzen auf vernetzte Hausgeräte, Der Tagesspiegel. http://www. tagesspiegel.de/wirtschaft/neuheiten-auf-der-ifa-hersteller-setzen-auf-vernetzte-hausgeraete/ 10631904.html. Accessed 4 Apr 2017

Vom Wege W (2016) Digitalisierung der EnergiewendeMarkteinführung intelligenter Messtechnik nach dem Messstellenbetriebsgesetz. Netzwirtschaften und Recht 2016:2-10

Von Oheimb D (2014) IT Security architecture approaches for smart metering and smart grid

Welchering P (2016) Ohne abgesicherte Infrastruktur kommt das Desaster, Deutschlandfunk. http://www.deutschlandfunk.de/datenschutz-im-smart-home-ohne-abgesicherte-infrastruktur. 684.de.html?dram:article_id=351502. Accessed 4 Apr 2017

Wiesemann HP (2011a) Smart Grids—Die intelligenten Netze der Zukunft. MMR 14(4):213-214

Wiesemann H (2011b) IT-rechtliche Rahmenbedingungen für intelligente Stromzähler und Netze. MMR 14(6):355-359

Zhang Z (2011) Smart Grid in America and Europe-Part I. Public Util Fortn 2011:46-50

\section{Author Biographies}

Max v. Schönfeld Dipl.-Jur., research associate at the Institute for Information, Telecommunication and Media Law (ITM) at the University of Münster. He holds a law degree from the University of Münster.

Nils Wehkamp B.Sc., research assistant at the Institute for Information, Telecommunication and Media Law (ITM) at the University of Münster. He holds a degree in business informatics from Stuttgart and studies law and economics in Münster. 
Open Access This chapter is licensed under the terms of the Creative Commons Attribution 4.0 International License (http://creativecommons.org/licenses/by/4.0/), which permits use, sharing, adaptation, distribution and reproduction in any medium or format, as long as you give appropriate credit to the original author(s) and the source, provide a link to the Creative Commons license and indicate if changes were made.

The images or other third party material in this chapter are included in the chapter's Creative Commons license, unless indicated otherwise in a credit line to the material. If material is not included in the chapter's Creative Commons license and your intended use is not permitted by statutory regulation or exceeds the permitted use, you will need to obtain permission directly from the copyright holder.

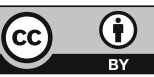

